\title{
DINAMIKA PEMBANGUNAN MANUSIA BERBASIS GENDER DI INDONESIA
}

\author{
Muhammad Arif Fahrudin Alfana ${ }^{1}$ Desta Fauzan $A^{2}$ Warastri Laksmiasri ${ }^{3}$ Ayu \\ Rahmaningtias $^{3}$ \\ arif.fahrudin@ugm.ac.id
}

\section{INTISARI}

Tujuan dari penelitian ini adalah untuk melihat tingkat keberhasilan pembangunan sehingga mampu meningkatkan pencapaian pembangunan manusia serta mampu mengurangi perbedaan pencapaian antara perempuan dan laki-laki di berbagai bidang yang di representasikan dengan indeks pembangunan gender (IPG) dan indeks pemberdayaan gender (IDG). Tujuan kedua adalah mengetahui pencapaian pembangunan manusia berbasis gender saat ini dengan menggunakan IPG maupun IDG. Data yang digunakan dalam penelitian ini adalah data sekunder. Data sekunder merupakan jenis data yang yang diperoleh dari penelitian orang lain atau sumber yang telah dipublikasikan. Data yang digunakan bersumber dari Biro Pusat Statistik (BPS) yang bekerjasama dengan BAPPENAS dan UNDP. Analisis data dilakukan dengan analisis deskriptif.

Hasil dari penelitian ini adalah selama periode 1996-2010 telah terjadi dinamika pembangunan manusia berbasis gender di Indonesia. Secara umum baik IPG dan IDG mengalami kenaikan setiap tahunnya. Hanya saja pada 1999 di beberapa provinsi di Indonesia mengalami penurunan nilai IPG dan IDG. Faktor krisis ekonomi menjadi penyebab menurunnya pembangunan manusia berbasis gender di Indonesia.Pencapaian IDG dan IPJ di Indonesia saat ini telah menuju ke arah perbaikan. Peningkatan indikator pembentuknya seperti usia harapan hidup, semakin berpendidikannya perempuan serta semakin naiknya porsi perempuan yang duduk di parlemen menjadikan pembangunan manusia berbasis gender di indonesia dapat dikatakan baik.

Kata Kunci: pembangunan manusia, pembangunan gender, pemberdayaan gender

\section{ABSTRACT}

The aim of this reseach is to describe achievement of human development and achievement between women and men that are represented by the gender development index (GDI), and the gender empowerment index (IDG). The second, are to determine the achievement of gender-based human development currently using GDI and IDG. The data used in this study is secondary data. Secondary data is data collected from various local government agencies. The data are obtained from the Central Bureau of Statistics (BPS) in cooperation with BAPPENAS and UNDP. Data Analysis is conducted by using a descriptive analysis.

The results of this study are for the period 1996-2010 there has been a gender-based dynamics of human development in Indonesia. In general, both IPG and IDG increase each year. Only in 1999 in several provinces in Indonesia impaired IPG and IDG. The economic crisis was the cause of the decline of gender-based human development in Indonesia. Achievement IDG and IDG in Indonesia has toward improvement. Increased constituent indicators such as life expectancy, more educated women and the rising share of women in the parliament to make gender-based human development in Indonesia can be said to be good.

Keywords: human development, gender development, gender empowerment

${ }^{1}$ Dosen Fakultas Geografi UGM; Peneliti PSKK UGM, ${ }^{2,3}$ Fakultas Geografi UGM, ${ }^{4}$ S2 Kependudukan UGM 


\section{PENDAHULUAN}

Perempuan adalah sumberdaya manusia yang jumlahnya besar dan memiliki potensi yang tinggi dalam kaitannya sebagai subyek dan obyek pembangunan. Tercatat berdasarkan data sensus penduduk 2010 jumlah perempuan Indonesia mencapai 118.010.413 jiwa atau 49,6 persen dari total penduduk. Sayangnya jumlah yang besar tersebut tidak dibarengi dengan kualitas perempuan yang tinggi pula. Hal ini dapat dilihat dari ketertinggalanketertinggalan perempuan terhadap laki-laki baik di sektor pendidikan, pekerjaan, pendapatan, maupun sektor lainnya.

Berdasarkan laporan pencapaian MDGs pada 2011 menggambarkan bagaimana perempuan masih tertinggal dari laki-laki sehingga mencerminkan pembangunan berbasis gender belum tercapai secara penuh. Tercatat dari segi pendidikan, rasio APM dan rasio melek huruf perempuan terhadap laki-laki belum mencapai target 100 persen. Dari sektor ketenagakerjaan kontribusi perempuan dalam sektor upahan di sektor non pertanian baru mencapai 36,6 persen. Sedangkan dilihat dari segi pemberdayaan, proporsi perempuan yang berada di parlemen baru mencapai angka 18,4 persen (Bappenas, 2011). Segala ketertinggalan tersebut menggambarkan bahwa perempuan masih belum berdaya.

Sebagai bagian terbesar dari sumberdaya manusia, perempuan memiliki peran strategis dalam kehidupan. Peran penting tersebut tercermin dalam segala aspek kehidupan baik dalam keluarga, masyarakat bahkan negara. Untuk itulah, untuk memaksimalkan peran yang begitu besar perempuan harus memiliki kulitas yang dapat diandalkan. Kualitas manusia, baik laki-laki atau perempuan, dapat dikatakan tinggi jika memiliki pilihan-pilihan hidup yang lebih baik. Pilihan-pilihan tersebut meliputi pendidikan dan ketrampilan yang tinggi, tingkat kesehatan yang tinggi dan pendapatan yang tinggi pula.

Meskipun saat ini upaya untuk meningkatkan peran dan kualitas perempuan dalam pembangunan telah banyak dikembangkan, akan tetapi kesenjangan gender masih terjadi di berbagai lini dibandingkan dengan laki-laki. Paradigma perempuan yang masih dianggap sebagai "konco wingking" sedikit banyak mempengaruhi peran perempuan kala berkiprah di lingkungannya. Padahal jumlah perempuan yang banyak merupakan modal pembangunan yang potensial jika dikembangkan secara tepat atau dengan kata lain berkualitas. Peran sumber daya manusia (SDM) perempuan yang berkualitas paling tidak memiliki dampak pada dua (2) hal. Pertama, dengan kualitas yang dimiliki, perempuan akan menjadi mitra kerja aktif laki-laki dalam mengatasi masalah-masalah sosial, ekonomi dan politik yang diarahkan pada pemerataan pembangunan. Kedua, perempuan yang berkualitas turut mempengaruhi kualitas generasi penerus, mengingat fungsi reproduksi perempuan berperan 
dalam mengembangkan sumber daya manusia di masa datang. Tetapi pada kenyataannya, selama ini peran serta kaum perempuan dalam pelaksanaan program pembangunan masih belum dimanfaatkan secara optimal. Faktor penyebab belum optimalnya peran serta perempuan dalam pembangunan karena masih rendahnya kualitas sumber daya perempuan sehingga tidak mampu untuk bersaing dalam berbagai bidang dengan mitra sejajarnya.

Kemampuan perempuan untuk menikmati dan berperan aktif dalam pembangunan masih terkendala dan masih menjadi masalah utama dalam pembangunan. Ketertinggalan peran perempuan dalam bidang pendidikan, kesehatan, ekonomi, politik dan lainnya terlihat dengan jelas oleh data-data statistik yang menggambarkan partisipasi perempuan masih rendah. Untuk mengatasi masalah tersebut, maka pembangunan perempuan harus dilakukan dengan tepat sasaran. Pembangunan yang dilakukan harus sesuai dengan kebutuhan dan didukung oleh data yang akurat sehingga indikator-indikator pembangunan perempuan yang masih rendah dapat digenjot untuk mencapai hasil yang maksimal.

Indeks Pembangunan Gender (IPG) dan Indeks Pemberdayaan Gender (IDG) merupakan indeks yang dapat menggambarkan pembangunan manusia berbasis gender. Dengan menggunakan indeks ini akan dapat dilihat seberapa besar pencapaian pembangunan gender di Indonesia berdasarkan pencapaian perempuan dalam mengkases kemampuan dasar dan melihat tingkat keterlibatan perempuan dalam proses pengambilan keputusan dibidang politik dan ekonomi.

Berdasarkan alasan tersebut maka dibutuhkan analisis trend perkembangan pembangunan berbasis gender. Analisis trends merupakan suatu metode analisis yang ditujukan untuk melakukan suatu estimasi atau peramalan pada masa yang akan datang dengan melihat kejadian yang telah terjadi di masa lalu. Untuk itu maka dibutuhkan berbagai macam informasi (data) yang cukup banyak dan diamati dalam periode waktu yang relatif cukup panjang, sehingga hasil analisis tersebut dapat mengetahui sampai berapa besar fluktuasi yang terjadi dan faktor-faktor apa saja yang memengaruhi terhadap perubahan tersebut. Hal ini menjadi penting sebagai salah satu langkah dalam penciptaan pembangunan yang berkelanjutan yang tepat sasaran khususnya dalam bidang pembangunan gender. Berdasarkan hal tersebut, maka rumusan masalah dalam penelitian ini adalah:

1. Bagaimana dinamika perkembangan pembangunan manusia berbasis gender di Indonesia?

2. Bagaimana pencapaian pembangunan manusia berbasis gender di Indonesia? Dengan berpijak pada hal tersebut maka ditentukan judul penelitian Dinamika Pembangunan Manusia Berbasis Gender Di Indonesia. 


\section{SEJARAH PEMBANGUNAN MANUSIA}

Jumlah penduduk yang semakin bertambah dengan ektrim menyebabkan kekhawatiran yang mendalam dari para ahli kependudukan. Bayangan mengenai permasalahan kependudukan yang kompleks membentuk terjadinya kesepakatan dunia internasional bahwa jumlah penduduk harus ditekan dan kualitas penduduk harus ditingkatkan. Sejak saat itulah muncul istilah pembangunan atau pengembangan sumber daya manusia dari alih bahasa human development.

Sejarah kebijakan dan sasaran pembangunan manusia dapat ditelusuri secara bertahap sejak 1950-an sampai 2015. Sebelum periode 1950-an masih belum jelas sasaran dan tujuan karena sebagian besar negara masih membenahi negaranya sehabis perang Perang Dunia II. Pada periode 1950-1960 arah pembangunan masih terfokus pada pertumbuhan ekonomi (EGOP) sebagai indikator utama. Kemudian disusul dengan indikator pemenuhan kebutuhan dasar menusia periode 1960-1970. "Human capability" menjadi prioritas utama yang harus dicapai. Kemudian pada 1970-1980 lebih fokus pada pembangunan kualitas fisik dengan indikator Indeks Mutu Hidup (IMH) atau PQLI.

Pada tahun 1990 United Nations Development Programme (UNDP) memperkenalkan konsep Indeks Pembangunan Manusia (Human Development Index), sebagai paradigma baru model pembangunan menggantikan PQLI (Physical Quality of Life Indeks) atau disebut indeks mutu hidup yang dianggap sudah tidak lagi relevan. UNDP (1990) merumuskan bahwa pembangunan sumber daya manusia merupakan suatu proses meningkatkan pilihan-pilihan kehidupan yang lebih baik. Pengertian ini lebih ditujukan kepada peningkatan kesehatan, pendidikan, dan pendapatan. Dalam bahasa yang lebih mudah dipahami adalah hidup lebih lama dan sehat, berpendidikan cukup dan memiliki ketrampilan dan mempunyai pendapatan yang cukup untuk pemenuhan kebutuhan dasar minimal.

Indeks Pembangunan Manusia (IPM atau HDI) yang didasarkan pada perluasan pilihan-pilihan hidup yang lebih baik seperti hidup lebih lama dan sehat, lebih berpendidikan dan terampil agar mendapatkan penghasilan yang cukup untuk pemenuhan kebutuhan dasar. Pada sampai ini (2012) indikator IPM masih digunakan sebagai tolak ukur pembangunan dengan beberapa penyempurnaaan terhadap variabel pembentuknya. Kemudian sejak 1995 dikembangkan pula indikator pembangunan dan pemberdayaan gender dengan parameter GDI (Indeks Pemberdayaan Gender) dan GEM (Indeks Pemberdayaan Gender). Sejak tahun 2000 dideklarasikan pembangunan era millenium III (2000-2015) dengan menggunakan tahun dasar 1990. Keberhasilan dan kegagalan pembangunan sumber daya manusia dapat dilihat dari tujuan dan sasaran Millenium Development Goals (MDGs). Perjalnan sejarah pembangunan manusia dapat dilihat pada Gambar 1. 


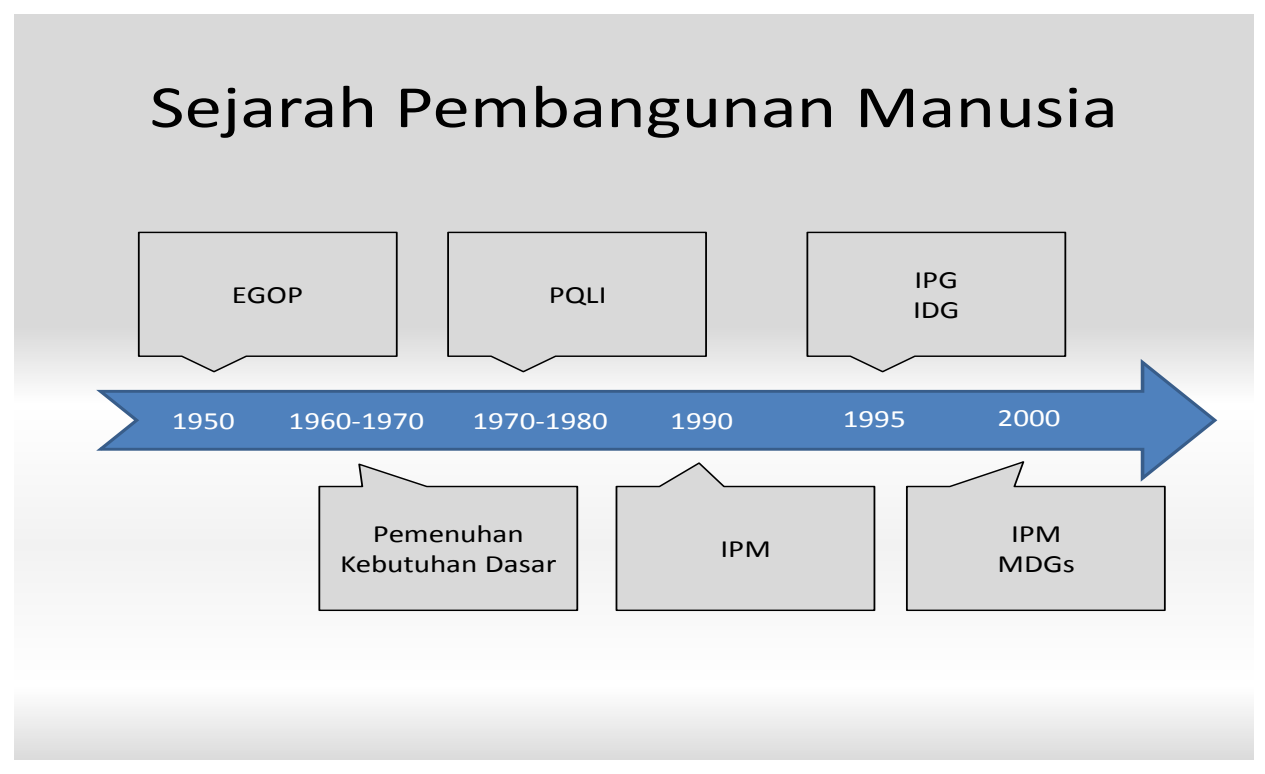

Gambar 1. Sejarah pembangunan Manusia

\section{INDEKS PEMBANGUNAN GENDER}

Pembangunan manusia yang dilakukan diarahkan dan ditujukan untuk seluruh penduduk tanpa membedakan jenis kelamin tertentu. Meskipun demikian pada kenyataannya perempuan senantiasa tertinggal dalam pencapaian kualitas hidup. Ketertinggalan ini disebabkan oleh berbagai persoalan pelik yang seringkali saling berkaitan antara satu dengan lainnya. Persoalan paling penting yang menghalangi upaya peningkatan kualitas hidup perempuan adalah pendekatan pembangunan yang mengabaikan isu tentang kesetaraan dan keadilan gender. Padahal sesuai amanah pemerintah dalam Undang-undang jelas sekali disebutkan bahwa pembangunan adalah hak bagi setiap warga negara.

Beberapa ukuran tentang kesetaraan dan keadilan gender telah digunakan banyak pihak, meski ukuran tersebut masih bersifat tunggal (single variable). Namun di dalam perkembangan waktu serta tuntutan akan tingkat keakurasian, maka ukuran yang bersifat komprehensif dan representatif mutlak dibutuhkan. UNDP melalui Laporan Pembangunan Manusia Tahun 1995 memperkenalkan ukuran pembangunan manusia yang bersifat gabungan (komposit) dari empat indikator, yang menyoroti tentang status perempuan khususnya mengukur prestasi dalam kemampuan dasar. Ukuran komposit yang dimaksud adalah Indeks Pembangunan Gender (IPG).

Pembangunan gender atau pembangunan yang berhubungan dengan gender (Gender Development atau Gender Related Development), ditujukan untuk mengetahui ada tidaknya ketimpangan yang terjadi antara laki-laki dan perempuan dalam pembangunan. Ketimpangan di antara laki-laki dan perempuan dinyatakan dalam suatu angka atau indeks. Semakin besar ketimpangan di antara keduanya dalam pembangunan manusia, semakin rendah nilai ideks 
tersebut. Variabel yang digunakan untuk menghitung indeks pembangunan gender (GDI atau IPG) adalah:

1) Proporsi jumlah penduduk laki-laki terhadap perempuan.

2) Usia harapan idup (laki-laki dan perempuan).

3) Persentase melek huruf (laki-laki dan perempuan).

4) Rata-rata lama sekolah (laki-laki dan perempuan).

5) Persentase penduduk aktif secara ekonomi (TPAK) laki-laki dan perempuan.

6) Upah di luar sektor pertanian (laki-laki dan perempuan).

7) Paritas daya beli (purchasing power parity/PPP).

Setiap variabel, kecuali proporsi penduduk dan paritas daya beli (PPP) dihitung indeks. Akhirnya didapatkan:

(1) indeks usia harapan hidup

(2) indeks pendidikan

(3) indeks distribusi pendapatan.

Proporsi penduduk perempuan dan laki-laki serta paritas daya eli digunakan seagai faktor penimbang. Indeks pembangunan gender (IPJ) dihitung dengan cara:

IPJ = ( Indeks Usia Harapan Hidup + Indeks Pendidikan + Indeks Distribusi Pendapatan ) / 3

atau dapat dinyatakan dengan rumus sebagai berikut:

$$
\text { IPJ }=1 / 3\left[\left(X_{\text {ede (1) }}+X_{\text {ede }(2)}+I_{\text {inc-dis }}\right)\right]
$$

dimana:

$\mathrm{X}_{\text {ede (1) }}=\mathrm{X}_{\text {ede }}$ usia harapan hidup

$\mathrm{X}_{\text {ede (2) }}=\mathrm{X}_{\text {ede }}$ pendidikan

$I_{\text {inc-dis }}=$ Indeks distribusi pendapatan

\section{INDEKS PEMBERDAYAAN GENDER}

Pemberdayaan Gender ditujukan untuk mengetahui partisipasi perempuan dalam proses pengambilan keputusan di bidang politik dan ekonomi. Variabel yang digunakan dalam pengukuran pemberdayaan gender (gender empowerment) adalah:

1) Peran perempuan di bidang pengambilan keputusan politik diukur dengan keanggotaan DPR dan DPRD. 
2) Peran perempuan di bidang ekonomi diukur seberapa banyak perempuan yang bekerja sebagai pekerja profesional, kepemimpinan, teknisi dan ketatalaksanaan atau pekerja terampil.

3) Penguasaan sumber daya ekonomi yaitu perkiraan penghasilan perempuan dan lakilaki.

Dalam perhitungan Indeks Pemberdayaan Gender terlebih dahulu dihitung EDEP yaitu suatu indeks untuk setiap pembentuk IDG berdasarkan persentase ekuivalen dengan distribusi yang merata. Dari setiap komponen pembentuk tersebut nilai EDEPnya dibagi 50. Angka 50 dianggap sebagai kombinasi yang ideal dari setiap kelompok gender untuk semua pembentuknya. Komponen pengambilan keputusan disusun dari dua indikator yaitu pekerja manajerial dan administrasi serta pekerja profesional dan teknisi. Komponen keterwakilan di parlemen diambil dari DPR, DPRD propinsi dan DPRD kabupaten/kota. IDJ dapat dihitung dengan cara:

$$
\text { IDJ }=1 / 3\left[\left(I_{\text {par }}+I_{\mathrm{Dm}}+I_{\text {inc-dis }}\right)\right]
$$

dimana:

$I_{\mathrm{par}}=$ Indeks keterwakilan di parlemen

$\mathrm{I}_{\mathrm{Dm}}=$ Indeks pengambilan keputusan

$\mathrm{I}_{\text {inc-dis }}=$ Indeks distribusi pendapatan

\section{TUJUAN PENELITIAN}

Tujuan yang ingin dicapai dalam penelitian ini antara lain untuk melihat dinamika perkembangan pembangunan manusia berbasis gender di Indonesia. Tujuan kedua, untuk mengetahui dinamika indikator-indikator penyusun pembangunan manusia berbasis gender di Indonesia.

\section{METODE PENELITIAN}

Penelitian ini merupakan suatu kajian mengenai dinamika perkembangan pembangunan manusia berbasi gender di Indonesia berdasarkan analisi Indeks Pembangunan Gender dan Indeks Pemberdayaan Gender. Penelitian ini berdasarkan obyeknya merupakan penelitian survey dengan metode kuantitatif untuk analisisnya. Sedangkan berdasarkan eksistensi populasinya, penelitian ini menggunakan metode sampling.

Daerah yang diteliti adalah Indonesia dengan unit analisi provinsi. Pertimbangan unit analisis provinsi adalah untuk melihat dinamika perkembangan pembangunan gender yang masih dapat tercover oleh data. Penyusun membatasi ruang lingkupnya hanya membahas 
bagaimanakah perbandingan perkembangan pembangunan gender di provinsi di Indonesia pada 1996-2010.

Metode pengumpulan data dilakukan dengan menggunakan metode kualitatif. Data yang digunakan dalam penyusunan laporan ini bersumber dari Laporan Pembangunan Manusia menurut kabupaten atau kota di Indonesia terbitan dari UNDP, Bappenas dan BPS. Data Pembangunan Manusia, khususnya data IPG dan IDG dikumpulkan berdasar empat titik waktu 1996, 1999, 2002 dan 2010 yang didasarkan pada tahun sebelum krisis, setelah krisis, masa pulih krisis serta kondisi terkini. Analisa data adalah kegiatan mengubah data hasil penelitian menjadi informasi yang dapat digunakan untuk mengambil kesimpulan dalam suatu penelitian. Adapun analisis data yang digunakan dalam penelitian ini menggunakan analisis deskriptif dan analisis komparasi

\section{PEMBAHASAN}

Konsep pembangunan sejatinya menempatkan manusia sebagai perspektif pembangunan dimana manusia selain berperan sebagai pelaku pembangunan, juga menjadi fokus dan tujuan akhir proses pembangunan. Pembangunan yang dilakukan sejatinya tidak boleh mengutamakan salah satu pihak dan mengesampingkan pihak yang lain sehingga tercipta keselarasan dan kesetaraan. Indikator yang digunakan untuk mengetahui tingkat kesetaraan tersebut adalah Indeks Pembangunan Gender (IPG) dan Indeks Pemberdayaan Gender (IDG). Kesetaraan gender ini dapat dimaknai sebagai kesamaan antara laki-laki dan perempuan untuk memperoleh kesempatan dan hak-hak hidup yang diwujudkan dalam pembangunan (BPS, Bappenas dan UNDP, 2004).

\section{Indeks Pembangunan Gender di Indonesia}

Indeks Pembangunan Gender (IPG) pada dasarnya sama dengan Indeks Pembangunan Manusia (IPM) yaitu merupakan suatu indeks untuk mengetahui pencapaian pembangunan manusia,namun Indeks Pembangunan Gender (IPG) lebih mengacu pada data terpilah antara laki-laki dan perempuan. Pemilahan antara laki-laki dan perempuan ini untuk mengetahui kondisi pembangunan antara laki-laki dan perempuan, mengingat perempuan merupakan sumberdaya potensial dalam proses pembangunan yang juga berperan dalam pembangunan secara keseluruhan akan tetapi justru perempuanlah yang dirugikan dalam pembangunan.

Pembangunan gender di Indonesia secara umum mengalami peningkatan dari tahun 1996-2010, hanya saja nilai IPG sedikit menurun pada tahun 1999 (Gambar 2). Penurunan 
nilai IPG ini disebabkan karena adanya peristiwa kekisruhan yang menuntut diadakannya reformasi. Peristiwa kekisruhan ini telah berdampak sistemik terhadap pembangunan, dimana pada waktu itu terjadi pergolakan di berbagai daerah di Indonesia seperti penjarahan dan tindakan kriminal lainnya yang kemudian berdampak terhadap penurunan kegiatan ekonomi. Peristiwa tersebut tidak hanya mengakibatkan berhentinya kegiatan ekonomi sementara tetapi juga mengakibatkan terjadinya inflasi yang besar kala itu sebagai bukti dari terjadinya krisis moneter. Krisis keuangan yang terjadi telah mengakibatkan semakin banyaknya jumlah penduduk miskin sehingga daya beli masyarakat terhadap suatu barang ataupun jasa juga semakin menurun. Adanya proses pembangunan kembali (recovery) yang dilakukan pasca peristiwa kekisruhan 1998 secara perlahan meningkatkan kegiatan ekonomi kegiatan pembangunan lainnya termasuk pembangunan gender di Indonesia. Peningkatan ini tidak terlepas dari upaya berbagai pihak dalam mendorong kemajuan pembangunan terutama dalam peningkatan kapabilitas perempuan untuk mencapai kualitas hidup yang lebih baik.

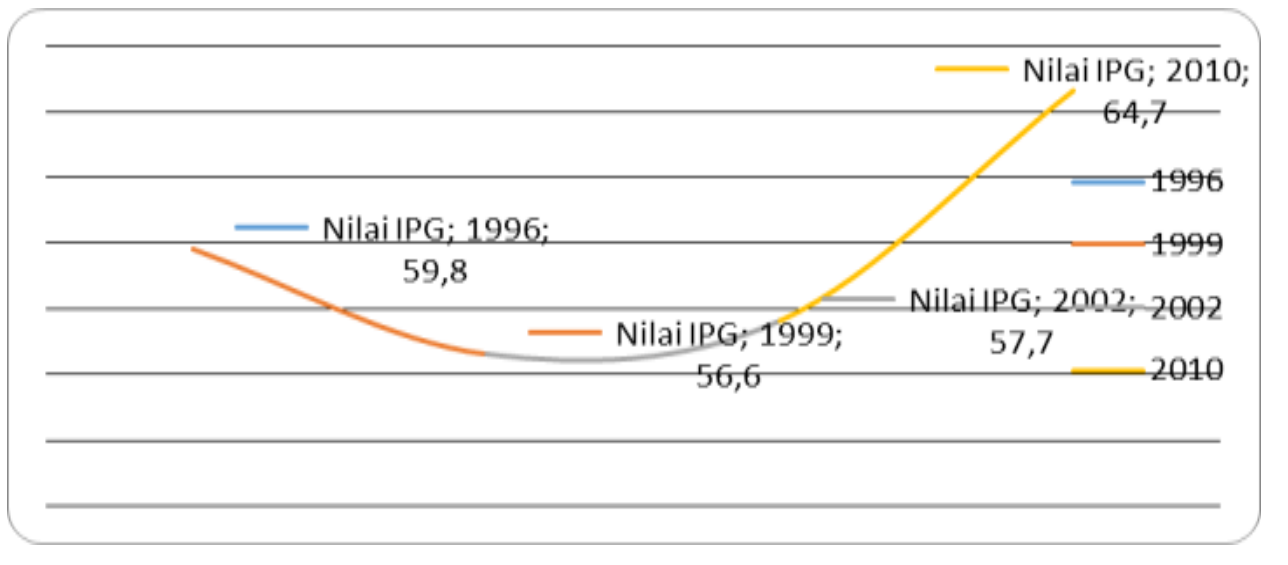

Gambar 1. Grafik Dinamika IPG di Indonesia Sumber: Hasil Olahan, 2014

Indeks Pembangunan Gender (IPG) Indonesia tahun 1996-2010 mengalami variasi nilai dan cenderung mengalami peningkatan di setiap provinsi. Nilai indeks pembangunan gender (IPG) tahun 1996 memiliki nilai yang cukup tinggi yaitu memiliki nilai indeks lebih dari lima puluh, akan tetapi nilai ini kemudian menurun pada tahun 1999. Penurunan ini disebabkan karena adanya peristiwa kekisruhan politik yang menuntut era reformasi dan adanya krisis moneter. Akan tetapi nilai IPG kembali meningkat pada tahun 2002. Hal ini menunjukkan bahwa proses recovery yang telah dilakukan secara perlahan mampu meningkatkan kembali proses pembangunan. Peningkatan pembangunan ini terus berlanjut dan menunjukkan peningkatan yang cukup tinggi pada tahun 2010. Kondisi ini menunjukkan 
bahwa Indonesia telah mampu pulih dari keterpurukan akibat krisis moneter, mengingat tidak mudah untuk melakukan pembangunan kembali pada berbagai aspek yang dulu sempat ambruk akibat adanya krisis moneter. Dinamika IPG provinsi-provinsi di Indonesia dalam kurun waktu 1996-2010 dapat dilihat pada Gambar 2. 


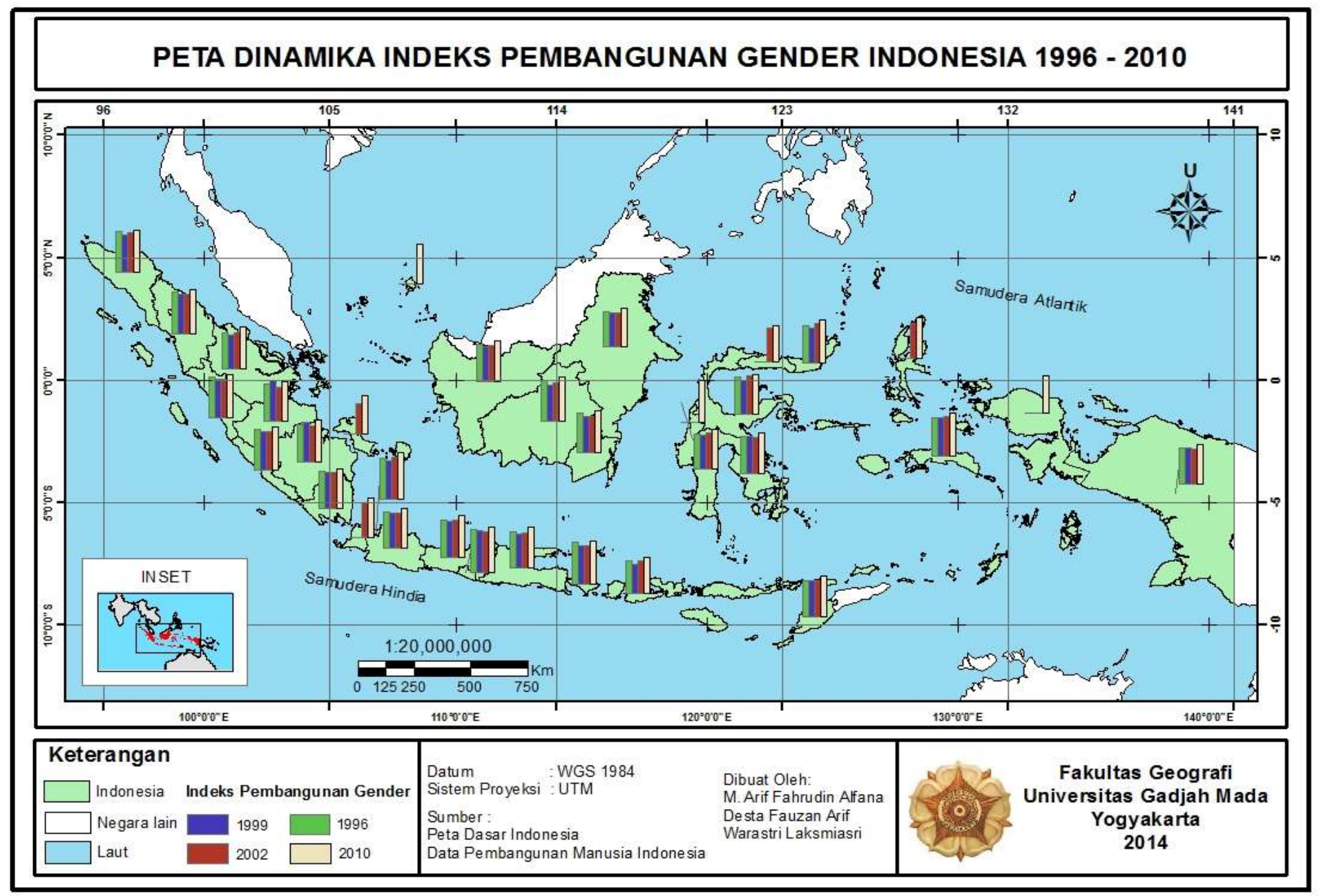

Gambar 2. Peta Dinamika Indeks Pembangunan Gender Indonesia 1996-2010 
Pencapaian IPG provinsi di Indonesia dilihat berdasarkan tahun akhir penelitian yaitu tahun 2010. Berdasarkan pencapaian tersebut terlihat bahwa sembilan provinsi melebihi rata-rata IPG nasional yaitu sebesar 67,2 (Gambar 3). Provinsi tersebut diantaranya adalah Sumatera Utara, Sumatera Barat, Bengkulu, Jakarta, Yogyakarta, Bali, Kalimantan Tengah, Sulawesi Utara dan Maluku. Hal ini menunjukkan bahwa pembangunan manusia di Indonesia masih belum merata. Wilayah Indonesia bagian barat cenderung mengalami pembangunan yang lebih pesat dibandingkan wilayah bagian timur Indonesia sehingga wilayah bagian timur masih tertinggal dibandingkan Indonesia bagian barat.

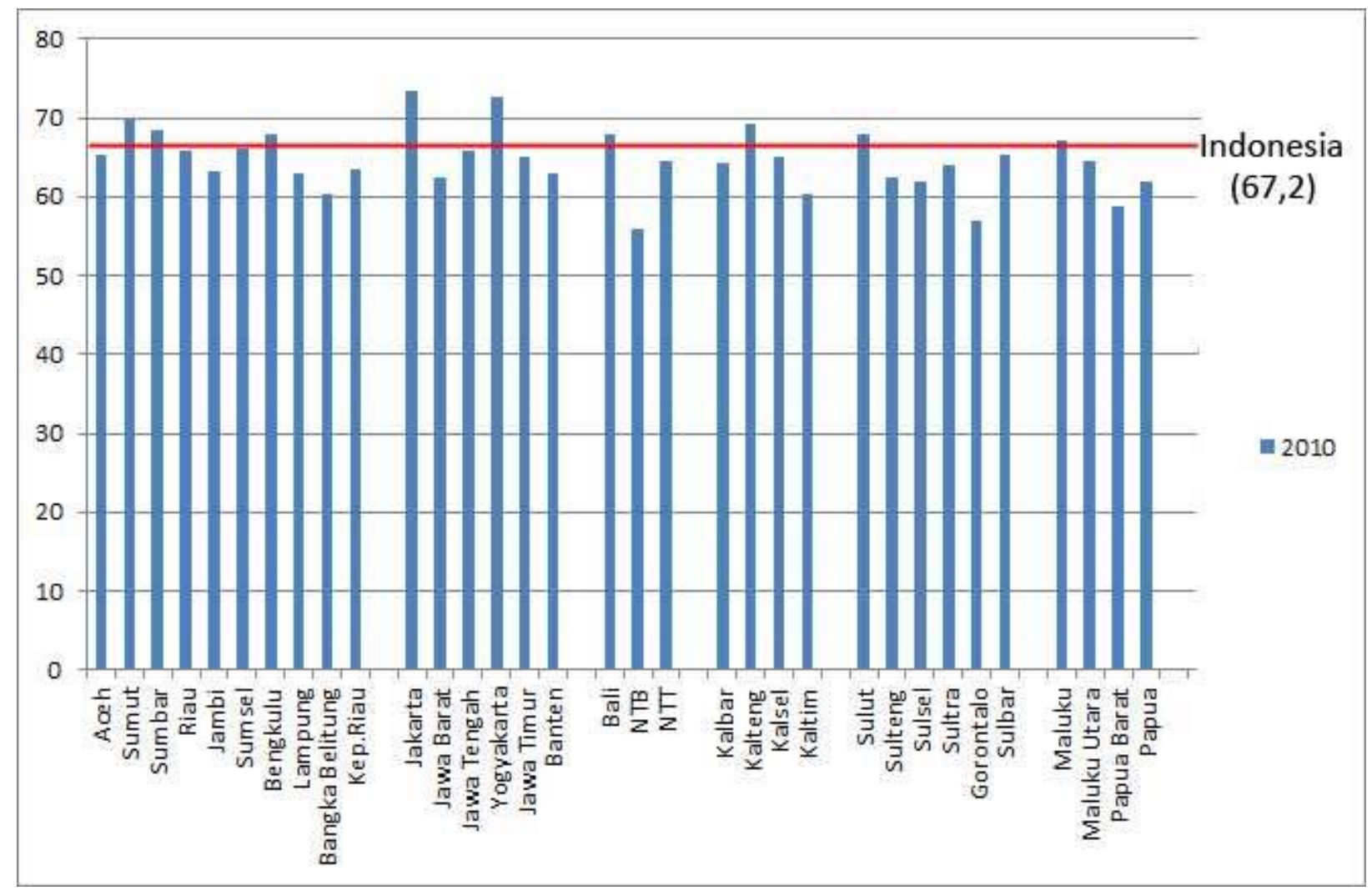

Gambar 3. Grafik IPG Provinsi di Indonesia Tahun 2010

Sumber: Hasil Olahan,2014

Ketimpangan pembangunan antar daerah berdampak pada kualitas sumberdaya manusia dimana kualitas sumberdaya manusia wilayah Indonesia bagian timur jauh tertinggal dibandingkan sumber daya manusia di wilayah Indonesia bagian barat. Hal ini dapat dilihat pada Gambar 3 nilai IPG di pulau Jawa dan Sumatera cenderung memiliki nilai yang tinggi dibandingkan pulau lain di wilayah Indonesia bagian timur seperti pulau Kalimantan, Sulawesi dan Papua. Menurut BPS dan KPPA (2011) banyak faktor yang menyebabkan ketimpangan pembangunan dan ketertinggalan pembangunan di wilayah 
Indonesia bagian timur, diantaranya terkait dengan kondisi alam dan kondisi Infrastruktur di bagian pedalaman wilayah timur Indonesia yang sangat buruk sehingga tercipta daerahdaerah kantong yang terisolasi.

Meskipun demikian, jika dilihat berdasarkan pencapaian IPG secara keseluruhan untuk semua provinsi menunjukkan peningkatan dari tahun-tahun sebelumnya. Hal ini menunjukkan bahwa adanya kemajuan pembangunan gender di semua provinsi di Indonesia tetapi masih diperlukan upaya lagi untuk pemerataan pembangunan antar provinsi dan pemerataan pembangunan antara laki-laki dan perempuan, mengingat kesenjangan gender masih terjadi di semua provinsi. Hal ini juga menunjukkan bahwa pembangunan kualitas manusia di suatu wilayah belum tentu berbanding lurus dengan kesetaraan gender.

\section{Indeks Pemberdayaan Gender di Indonesia}

Pada Gambar 4 menunjukkan bahwa pemberdayaan gender di Indonesia secara umum mengalami peningkatan dari tahun 1996-2010, hanya saja nilai IDG mengalami stagnasi pada kurun waktu 1999-2002. Seperti yang telah dibahas sebelumnya, penurunan nilai IDG ini disebabkan karena adanya peristiwa gejolak politik yang sedikit banyak mempengaruhi pemberdayaan perempuan secara umum.

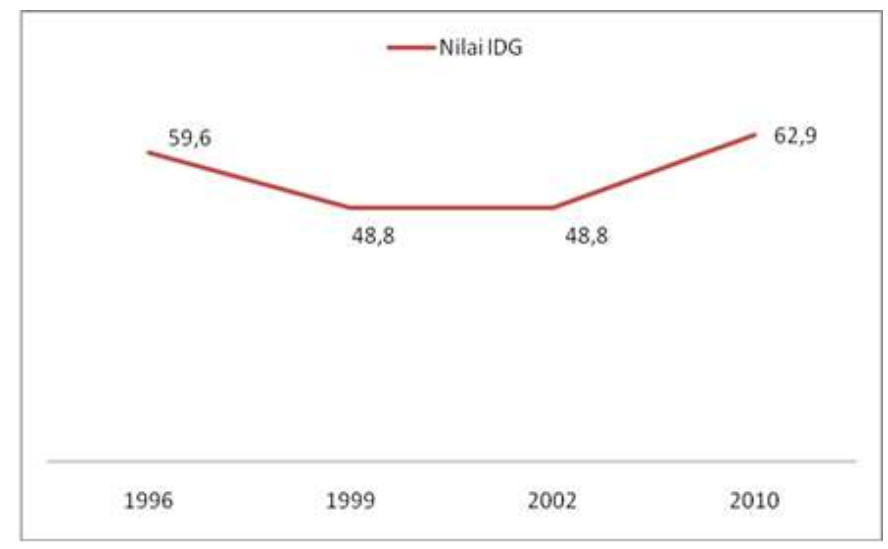

Gambar 4. Grafik Dinamika IPG di Indonesia Sumber: Hasil Olahan, 2014

Adanya proses pembangunan kembali (recovery) yang dilakukan pasca peristiwa kekisruhan 1998 secara perlahan meningkatkan kegiatan ekonomi kegiatan pembangunan lainnya termasuk pembangunan gender di Indonesia. Peningkatan ini tidak terlepas dari upaya berbagai pihak dalam mendorong kemajuan pembangunan terutama dalam peningkatan kapabilitas perempuan untuk mencapai kualitas hidup yang lebih baik.

Indeks Pemberdayaan Gender (IDG) Indonesia tahun 1996-2010 mengalami variasi nilai dan cenderung mengalami peningkatan di setiap provinsi. Nilai IDG tahun 1996 
memiliki nilai yang cukup tinggi yaitu memiliki nilai indeks lebih dari lima puluh, akan tetapi nilai ini kemudian menurun pada tahun 1999. Penurunan ini disebabkan karena adanya peristiwa kekisruhan politik yang menuntut era reformasi dan adanya krisis moneter. Akan tetapi nilai IDG kembali meningkat pada tahun 2002. Hal ini menunjukkan bahwa proses recovery yang telah dilakukan secara perlahan mampu meningkatkan kembali proses pembangunan. Peningkatan pembangunan ini terus berlanjut dan menunjukkan peningkatan yang cukup tinggi pada tahun 2010. Kondisi ini menunjukkan bahwa Indonesia telah mampu pulih dari keterpurukan akibat krisis moneter, mengingat tidak mudah untuk melakukan pembangunan kembali pada berbagai aspek yang dulu sempat ambruk akibat adanya krisis moneter. Dinamika IDG provinsi-provinsi di Indonesia dalam kurun waktu 1996-2010 dapat dilihat pada Gambar 5.

Kotak 2

\section{Dampak Krisis Terhadap Kaum Perempuan}

Dampak krisis terhadap 1997-1999 tidak bisa terungkap lewat data pengangguran karena menurut data tersebut justru jumlah pengangguran perempuan semakin menurun. Akan tetapi jika dilihat dari sudut lain, dampak krisis bagi perempuan adalah mereka semakin tidak berdaya karena jam kerja perempuan semakin panjang dan upah yang mereka terima hanya sekitar sepertiga dari upah yang diterima laki-laki. Selain itu dampak krisis bagi perempuan adalah masalah gizi buruk. Menurut survey dari Helen Keller International dan Univ. Diponegoro menyebutkan bahwa 17,5 persen perempuan di Jawa Tengah mengalami kekurangan gizi setelah setahun mengalami krisis ekonomi. Padahal sebelum itu perempuan yang mengalami gizi buruk sebesar 15 persen.

Sumber: Bappenas, NICEF (2000) dalam BPS, Bappenas dan UNDP, 2001 


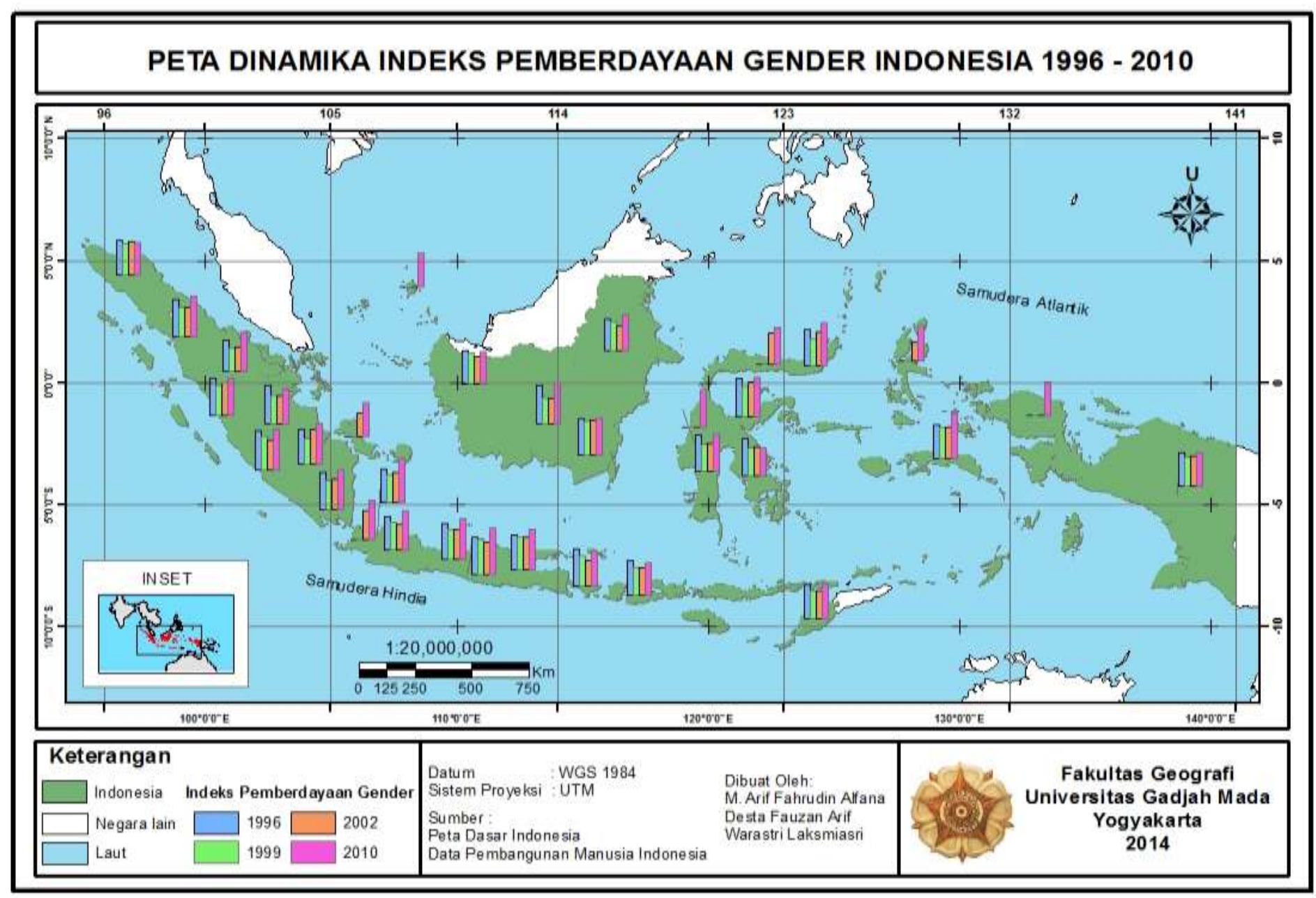

Gambar 5. Peta Dinamika Indeks Pemberdayaan Gender Indonesia 1996-2010 


\section{Analisis Indikator Pembentuk Indeks Pembangunan Gender}

Indeks Pendayagunaan Gender (IDG) merupakan salah satu indeks yang menunjukkan tolak ukut keaktifan perempuan pada ranah ekonomi dan politik, yang mencakup partisipasi berpolitik, partisipasi ekonomi dan pengambilan keputusan, serta penguasaan sumber daya ekonomi. Perhitungan IDG memiliki kesamaan dengan perhitungan IPG. Pertama-tama, EDEP yaitu indeks untuk masing-masing komponen berdasarkan persentase yang ekuivalendengan distribusi yang merata (Equally Distributed Equivalent Persentage) dihitung kemudian dibagi dengan nilai 50.Nilai 50 dianggap sebagaikontribusi ideal masing-masing kelompok gender untuk semuakomponen IDG. Tidak ada pembobotan khusus pada salah satu indikator dalam perhitungan IDG.

IDG berkaitan erat dengan dinamika kesetaraan gender pada lingkup nasional maupun internasional. Jaminan terhadap kesetaraan gender tersebut kemudian diatur dalam konstitusi negara maupun konferensi internasional karena dianggap sebagai hal yang tidak sepele. Manusia memiliki derajat dan hak-hak yang sama di dunia, walau begitu di dunia ini masih banyak pelanggaran ham yang mempermasalahkan gender sebagai pembedanya.

Seluruh warga negara Indonesia, laki-laki maupun perempuan, memiliki kedudukan yang sama di bidang hukum maupun politik. Hal itu telah dijamin pada Undang-Undang Dasar (UUD) Negara Republik Indonesia Tahun 1945 Pasal 2 dan Pasal 28, Undang-undang (UU) nomor 39 Tahun 1999 tentang Hak Asasi Manusiadengan bab khusus tentang Hak-hak Perempuan. Pada tataran internasional, kesetaraan antara laki-laki dan perempuan diatur pula oleh Perserikatan Bangsa-bangsa (PBB) pada Convention on the Elimination of All Forms of Discrimination Against Women (CEDAW) yang berlaku sejak 3 Desember 1981. Bab II pasal 7 CEDAW PBB menerangkaan bahwa:

"Negara-negara Peserta wajib melakukan segala langkah-tindak yang tepat untuk menghapus diskriminasi terhadap perempuan dalam kehidupan politik dan publik negara dan, khususnya, wajib memastikan bagi perempuan, setara dengan laki-laki, hak-hak:

(a) Untuk memberikan suara dalam semua pemilihan umum dan referendum dan untuk dapat dipilih dalam pemilihan untuk semua lembaga yang didasarkan atas pemilihan umum;

(b) Untuk berpartisipasi dalam perumusan kebijakan pemerintah dan pelaksanaannya dan untuk menduduki jabatan publik dan menjalankan segala fungsi publik pada seluruh tingkatan pemerintahan;

(c) Untuk berpartisipasi dalam organisasi-organisasi non-pemerintah dan asosiasi-asosiasi yang berkenaan dengan kehidupan publik dan politik negara."

Kesepakatan tingkat internasional tersebut diperjelas pada peraturan perundangundangan Indonesia seperti pada UU nomor 10 tahun 2008, Bab III Pasal 8 ayat 2d menjelaskan bahwa 
"partai politik dapat menjadi Peserta Pemilu setelah memenuhi persyaratan menyertakan sekurang-kurangnya 30\% (tiga puluh perseratus)keterwakilan perempuan pada kepengurusan partai politik tingkat pusat."

Berkas yang masuk akan diverifikasi oleh KPU mengenai kebenarannya. Seperti yang diatur pada Bab VII Pasal 58 ayat 2, bahwa apabila bakal calon masing-masing partai politik tidak memenuhi kuota 30\% keterwakilan perempuan, maka KPU kabupaten/kota memberikan kesempatan kepada partai politik untuk memperbaiki daftar calon tersebut.

Persyaratan tersebut dapat dikatakan sebagai persyaratan yang tidak mudah karena tidak banyak perempuan yang berminat maupun mampu untuk bergabung dalam ranah politik menjadi bagian dari pengambil keputusan. Untuk bisa terjun dalam hal politik pemerintahan, perempuan tersebut harus berdaya, yaitu mampu menyelesaikan kewajiban domestik maupun publik. Sektor domestik tak bisa lepas dari kodrat perempuan yang berperan sebagai ibu dan istri dalam suatu rumah tangga.

Menurut data Parliamentary Library from Commonwealth, state and territory parliamentary websites (2014), persentase keterlibatan perempuan pada perlemen di Australia tahun 2014 mencapai 29\%. Apabila dibandingkan dengan Indonesia, angka tersebut tentu masih lebih tinggi dibandingkan dengan angka keterlibatan perempuan di parlemen Indonesia, yaitu sebesar 17,49 pada tahun 2010 dan 18,04 pada tahun 2012 . Beberapa kendala yang menjadi penghambat tingginya nilai IDG Indonesia adalah keputusan publik keluarga, budaya, dan pendidikan.

Bagi sebagian besar keluarga di Indonesia, kehadiran dan keandilan perempuan, dalam hal ini adalah istri sekaligus ibu pada sektor domestik tidak dapat ditawar nilainya. Tidak semua istri mau untuk terlibat langsung pada pengambilan keputusan di negeri ini. Bahkan apabila istri mau dan mampu terlibat, ada kemungkinan bahwa tidak semua suami serta keluarga mengizinkan istrinya untuk terjun ke ranah itu. Hal itu tentu saja menjadikan beban bagi sebagian besar perempuan Indonesia untuk turut terjun dalam ranah politik yang hingga saat ini masih didominasi oleh kaum laki-laki. Di sisi lain, kebudayaan yang berkembang di Indonesia dewasa ini, terutama dari sudut pandang keagamaan, masih terdapat anggapan bahwa kehadiran perempuan sebagai pemimpin masih dianggap tabu. Pendidikan perempuan yang secara umum masih lebih rendah dibandingkan laki-laki (seperti yang terdapat pada data angka melek huruf dan rata-rata lama sekolah) menjadikan adanya kompetisi ketat dengan antara dua gender tersebut untuk memperebutkan kursi di pemerintahan. Hal itu turut menjadi penghambat berkiprahnya perempuan pada ranah pengambilan keputusan publik. Nilai indikator partisipasi wanita Indonesia di parlemen pun cenderung paling rendah bila dibandingkan nilai indikator lainnya pada IDG. 
Kondisi partisipasi wanita di Indonesia berdinamika dari tahun ke tahun. Secara nasional, angka keterlibatan wanita di parlemen pada tahun 1996 berada pada angka tertinggi 16.4. Angka tertinggi nilai tersebut menurun pada tahun 1999 menjadi 12.5. Krisis ekonomi secara tidak langsung telah mempengaruhi kondisi ini. Angka tertinggi keterlibatan wanita di parlemen secara nasional naik menjadi 14.7 pada tahun 2002 dan 28.89 pada tahun 2010. Dari aspek spasial, lokasi wilayah yang berhasil meraih angka tertinggi partisipasi wanita dalam parlemen berubah tiap tahunnya. Pada tahun 1996, nilai tertinggi indikator ini diperoleh oleh Provinsi Jambi. Pada tahun 1999, nilai tertinggi indikator ini diperoleh oleh Provinsi Kalimantan Timur. Pada tahun 2002, nilai tertinggi indikator ini diperoleh oleh Provinsi Sumatera Selatan. Pada tahun 2010, nilai tertinggi indikator ini diperoleh oleh Provinsi Maluku.

Di sisi lain, wilayah dengan nilai terendah partisipasi wanita di parlemen pun berbeda-beda dari waktu ke waktu. Provinsi Aceh memiliki nilai terendah indikator tersebut pada tahun 1996, yaitu sebesar 6,1. Pada tahun 1999, nilai terendah indikator tersebut diraih oleh Provinsi Riau dengan nilai 2,0. Provinsi Maluku Utara juga pernah mendapat nilai terendah pada tahun 2002, yaitu 0,0. Dengan kata lain, partisipasi wanita di parlemen pada Provinsi tersebut tidak ada. Setelah itu, pada tahun 2010 Kalimantan Barat mendapat nilai terendah pada indikator tersebut, yaitu sebesar 5,45. Wilayah yang memiliki nilai tertinggi dan terendah pada indikator ini tidak dapat diprediksikan dari tahun ke tahun. Hal tersebut disebabkan oleh sangat berpengaruhnya kondisi politik dan sosial dari berbagai wilayah.

Indikator lain pada IDG selain partisipasi wanita dalam parlemen adalah proporsi wanita pekerja profesional, teknisi, kepemimpinan dan ketatalaksanaan. Kondisi proporsi wanita pekerja profesional, teknisi, kepemimpinan dan ketatalaksanaan berbeda-beda pada setiap wilayah. Namun, tren partisipasinya dapat diamati pada setiap pulau.

Pada umumnya indikator ini memiliki nilai tertinggi bila dibandingkan dengan indikator lainnya pada setiap provinsi. Contohnya seperti provinsi-provinsi di Pulau Sulawesi. Nilai indikator ini pada wilayah tersebut jauh diatas nilai indikator partisipasi wanita di parlemen dan nilai partisipasi wanita di pendapatan kerja. Hal berbeda terlihat wilayah Bali - Nusa Tenggara. Pada Provinsi Bali, Provinsi Nusa Tenggara Barat, dan Nusa Tenggara Timur, nilai indikator proporsi wanita pekerja profesional, teknisi, kepemimpinan dan ketatalaksanaan pada wilayah tersebut tidak lebih besar dari nilai indikator partisipasi wanita di pendapatan kerja. Namun pada tahun 2010 nilai indikator proporsi wanita pekerja profesional, teknisi, kepemimpinan dan ketatalaksanaan pada wilayah tersebut sudah lebih besar dari nilai indikator partisipasi wanita di pendapatan kerja. Hal tersebut manunjukkan bahwa terdapat beberapa kemungkinan yang melatarbelakangi perubahan pola tersebut. 
Beberapa diantaranya adalah kecenderungan wanita untuk kalah saing memperebutkan posisi tersebut, serta masih adanya legitimasi masyarakat bahwa laki-laki lebih superior dibandingkan wanita pada posisi pekerjaan tersebut.

Anomali tren terkait nilai indikator wanita pekerja profesional, teknisi, kepemimpinan dan ketatalaksanaan juga terlihat pada beberapa provinsi di Pulau Jawa, yaitu DKI Jakarta, Provinsi Daerah Istimewa Yogyakarta, Provinsi Jawa Timur, dan Provinsi Banten pada tahun 2002. Pada tahun 1996, 1999, dan 2010, nilai indikator tersebut pada provinsiprovinvisi di Pulau Jawa selalu lebih tinggi dibandingkan nilai indikator partisipasi wanita di pendapatan kerja, namun pada tahun 2002, yang terjadi adalah kebalikannya pada keempat provinsi tersebut. Banyak kejadian di Indonesia yang dapat menjadi hal yang berpengaruh pada kondisi tersebut. Irian Jaya yang berganti nama menjadi Papua, lepasnya Timor Timur dari Indonesia, serta banyaknya teror bom, seperti tragedi bom Palu, bom Bali, dan bom di rumah makan cepat saji di Makassar merupakan kejadian nasional yang menghiasi negeri ini. Provinsi-provinsi yang berada di Pulau Jawa pada umumnya merupakan provinsi yang rentan terhadap kondisi nasional Indonesia.

Nilai indikator wanita pekerja profesional, teknisi, kepemimpinan dan ketatalaksanaan tertinggi di Indonesia pada tahun 1996, 1999, 2002, dan 2010 selalu diraih oleh Provinsi Sumatera Barat dengan nilai berturut-turut 54,3; 58,8; 58,3; 57,83. Kondisi tersebut tentu saja berkaitan dengan kondisi sosial yang ada pada wilayah tersebut. Sebagian besar penduduk Provinsi Sumatera Barat adalah suku Minang. Suku tersebut merupakan suku matrilineal, yaitu perempuan dianggap lebih superior daripada laki-laki. Hal tersebut mendukung tingginya partisipasi wanita pada ranah pekerja profesional, teknisi, kepemimpinan dan ketatalaksanaan.

Adapun nilai terendah indikator pekerja profesional, teknisi, kepemimpinan dan ketatalaksanaan pada tahun 1996, 1999, 2002, dan 2010 berturut-turut berada pada Provinsi Papua dengan nilai 27,8; 34,2; 30,6; 33,93. Rendahnya nilai indikator tersebut pada Provinsi Papua dipengaruhi oleh akses pendidikan dan kondisi sosial masyarakat yang ada. Tenaga kerja profesional, teknisi, kepemimpinan dan ketatalaksanaan masih didominasi oleh pria pada Provinsi tersebut.

Indikator terakhir pada IDG selain partisipasi wanita dalam parlemen dan indikator tenaga pofesional, teknisi, kepemimpinan dan ketatalaksanaan adalah proporsi wanita di pendapatan kerja. Kebalikan dari penjelasan mengenai tenaga pofesional, teknisi, kepemimpinan dan ketatalaksanaan, bahwa proporsi wanita di pendapatan kerja pada umumnya memiliki nilai yang lebih rendah daripada nilai indikator tenaga pofesional, teknisi, kepemimpinan dan ketatalaksanaan, walau diatas dari partisipasi wanita di parlemen. 
Nilai tertinggi indikator proporsi wanita di pendapatan kerja di Indonesia diraih oleh wilayah yang cenderung berbeda-beda tiap tahunnya. Seperti pada tahun 1996, nilai tersebut diraih oleh Provinsi Daerah Istimewa Yogyakarta dengan nilai 37,9. Pada tahun 1999 nilai tertinggi juga diraih oleh provinsi yang sama dengan jumlah nilai 45,6. Provinsi Aceh meraih nilai tertinggi proporsi wanita di pendapatan kerja pada tahun 2002 dengan nilai 49,6. Sedangkan Provinsi Nusa Tenggara Timur meraih nilai tertinggi pada tahun 2010 dengan nilai38,5.

Tren lebih tingginya nilai partisipasi wanita menjadi tenaga pofesional, teknisi, kepemimpinan dan ketatalaksanaan dari pada nilai proporsi wanita di pendapatan kerja menunjukkan bahwa upah yang diterima wanita pada bidang pekerjaannya tidak sebanyak laki-laki. Dari aspek upah yang diterima, dapat terlihat secara tidak langsung bahwa upah yang diterima tenaga pofesional, teknisi, kepemimpinan dan ketatalaksanaan tentu saja relatif besar dan konstan. Hal terbut masih menjadikan proporsi pendapatan wanita lebih rendah karena di Indonesia tidak adanya tuntutan bahwa wanita adalah tulang punggung keluarga apabila masih memiliki suami. Oleh karena itu, wanita di Indonesia pada umumnya tidak cenderung terlalu berusaha keras untuk mendapatkan upah melebihi suaminya. Bahkan pada beberapa kasus, upah istri yang lebih besar daripada suami dapat menjadi salah satu penyebab konflik rumah tangga. Di sisi lain, secara kodrati, wanita memiliki tanggung jawab di ranah domestik dan kondisi fisik wanita cenderung lebih lemah dibanding dengan laki-laki. Hal itu turut mempengaruhi perbedaan jumlah jam kerja serta jumlah penghasilan antara laki-laki dan perempuan.

Kondisi IDG Indonesia yang telah dijelaskan di atasmenimbulkan rasa gembira sekaligus mengkhawatirkan. Sisi positif dari kondisi IDG Indonesia tersebut adalah kesetaraan gender di Indonesia secara umum terjamin sehingga tidak ada hambatan bagi wanita untuk berkarir dan mengenyam pendidikan. Hal yang mengkhawatirkan adalah wanita yang memilih untuk berkarir sebaiknya tidak meninggalkan kodratnya untuk mengurus wilayah domestik pada rumah tangga. Tenaga pengganti untuk mengurus ranah domestik dewasa ini banyak ditemui dan relatif mudah didapatkan. Walau begitu, esensi dan peran ibu sekaligus istri dalam rumah tangga tetap tidak dapat digantikan oleh wanita lain. 


\section{DAFTAR PUSTAKA}

Bappenas. 2011. Laporan Pencapaian Tujuan Pembangunan Milenium di Indonesia 2011. Bappenas: Jakarta

Badan Pusat Statistik (BPS) dan Kementerian Pemberdayaan Perempuan dan Perlindungan Anak (KPPPA). 2011. Pembangunan Manusia Berbasis Gender 2011.Jakarta: CV. Permata Andhi

BPS, Bappenas dan UNDP. 2001. Menuju Konsensus Baru: Demokrasi dan Pembangunan Manusia di Indonesia. BPS, Bappenas dan UNDP: Jakarta

BPS. 2011. Indeks Pembangunan Manusia 2009-2010: Keterkaitan antara IPM, IPG dan IDG. Badan Pusat Statistik: Jakarta

BPS. 2011. Pembangunan Manusia Berbasis Gender. Kementerian Pemberdayaan Perempuan dan Perlindungan Anak (KPP dan PA): Jakarta

BPS. 2012. Indeks Pembangunan Manusia 2010-2011. Badan Pusat Statistik: Jakarta United Nations. 1993. Population and Development Planning. New York http://www.aph.gov.au/About_Parliament/Work_of_the_Parliament/Forming_and_Gove rning_a_Nation/parl

Tulisan ini merupakan bagian dari Prosiding Seminar Nasional Geografi Universitas Muhammadiyah Surakarta 2015 "Peran Geograf dan Peneliti dalam Menghasilkan Penelitian dan Pengabdian yang Berdayaguna Bagi masyarakat" 7 Maret 2015. 